\title{
Slaughterhouse By-Product Valorization: Hydrolysis Degree Modification for Higher Antimicrobial Recovery by Electroseparation
}

\author{
Rémi Przybylski ${ }^{1}$ - Laurent Bazinet ${ }^{2}$ - Mostafa Kouach ${ }^{3} \cdot$ Jean-François Goossens ${ }^{3}$. Pascal Dhulster ${ }^{1}$. \\ Loubna Firdaous $^{1} \cdot$ Naïma Nedjar-Arroume ${ }^{1}$
}

Received: 26 March 2020 / Accepted: 6 July 2020 / Published online: 10 July 2020

(c) The Author(s) 2020

\begin{abstract}
In the actual context of food safety and circular economy, the separation of the $\alpha 137-141$ antimicrobial peptide (TSKYR, $653 \mathrm{Da}$ ) coming from the hydrolysis of bovine hemoglobin, a non-valorized slaughterhouse by-product, and its reuse as a preservative agent for food products during storage would be of major interest. However, depending on the degree of hydrolysis (DH) of the bovine hemoglobin, the TSKYR peptide environment into the hydrolysate will be different and would impact its recovery yield by electrodialysis with ultrafiltration membranes (EDUF), a hybrid and eco-friendly technology. In this context, five DHs $(3,5,10,13$ and $18 \%)$ were investigated to study the influence of the peptide populations on the $\alpha 137-141$ selective separation by EDUF. It appeared from these results that the most appropriate DH was of 5\% since a lower population of peptides between 500 and $1000 \mathrm{Da}$ was present and the subunits of hemoglobin were already digested. Hence, an enrichment factor of about 13 folds for the $\alpha 137-141$ was obtained in comparison with the initial hydrolysate. At our knowledge, it was the first time that the effect of the hydrolysis degree of a protein is demonstrated to impact preferentially the separation of a specific peptide by EDUF.
\end{abstract}

\section{Graphic Abstract}

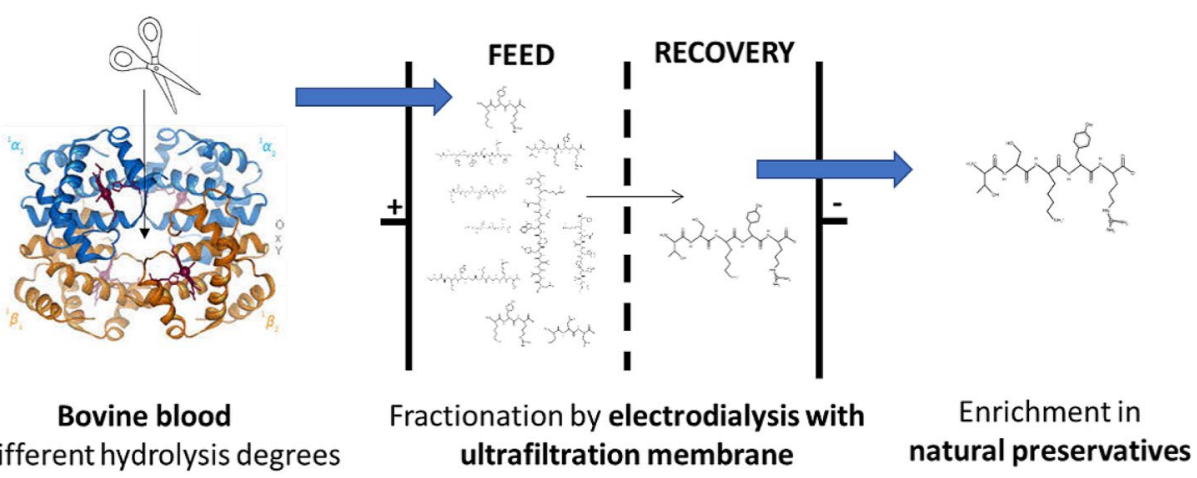

Keywords Antimicrobial peptide $\cdot$ Electrodialysis $\cdot$ Filtration membrane $\cdot$ Preservative $\cdot$ Valorization

Naïma Nedjar-Arroume

naima.nedjar@univ-lille.fr

1 Univ. Lille, INRA, ISA, Univ. Artois, Univ. Littoral Côte d'Opale, EA 7394 - ICV - Charles Viollette Institute, 59000 Lille, France

2 Institute of Nutrition and Functional Foods, Department of Food Sciences and Laboratoire de Transformation
Alimentaire et Procédés ElectroMembranaires (LTAPEM, Laboratory of Food Processing and ElectroMembrane Processes), Université Laval, Québec, QC G1V 0AV, Canada

3 University Lille, CHU Lille, EA 7365 - GRITA - Groupe de Recherche sur les formes Injectables et les Technologies Associées, PSM (Plateau de Spectrométrie de Masse), 59000 Lille, France 


\section{Statement of Novelty}

This work shows a new opportunity of a circular economy for meat industries. Indeed, high environmental impacts of slaughterhouse wastes could decrease by converting blood into natural preservatives. These bioproducts could be a great alternative for chemical additives largely used to protect food. Nevertheless, the separation of know and natural preservatives from slaughterhouse blood is not easy. This study shows how to maximize the recovery (and the efficiency) of the natural preservatives by using a new, eco-friendly and sustainable technology. Moreover, the obtained preservatives are safe and previously described as powerful antimicrobials. This work fits perfectly with the concept of waste bioconversion and shows a great proofconcept of circular economy for production of preservatives from slaughterhouse waste.

\section{Introduction}

Recently, due to the increasing pressure of the governments to decrease the wastes produced by the agri-food sector, the United Nations created a new program named "Transforming our world: 2030 for sustainable development". Therefore, the food industries had an urgent need for potential technological ways to answer this problematic [1-3]. In meat industry, a new global pressure is growing to minimize the environmental impact and to decrease the unutilized parts of animals not directly involved in meat processing. Indeed, this kind of by-products can be defined as substances or objects resulting from a production process not primarily aimed at producing. Nevertheless, slaughterhouse by-products are various like bones, skins, wool or blood and are rich in bioactive compounds $[4,5]$. Bovine blood is a by-product from slaughterhouse produced in large quantity all around the world since each slaughtered beef produces about $12 \mathrm{~L}$ of blood and considering that more than 4.3 million of beefs, only in France, were slaughtered in 2017 [4]. Blood contains large amount of hemoglobin, a protein not valorized since the main use of blood is focused on its colorless part, the plasma, for pharmaceutical and food industry applications [6, 7]. Indeed, after centrifugation of the raw bovine blood, the recovered red fraction contains mainly hemoglobin. This protein is broadly described as a rich source of bioactive peptides after enzymatic hydrolysis [8-10]. In addition, the antimicrobial activity of peptides generated from hemoglobin is particularly well-documented [11-14]. Antimicrobial peptides are particularly interesting due to their various structures and activities against pathogenic strains [15]. Their relative innocuity is due to their mechanism of action which is different from classical antibiotic [16]. Moreover, antimicrobial peptides are multifunctional and have generally another simultaneous bioactivity such as antioxidant [17]. Hence, antimicrobial peptides could be potential candidate for the substitution of various synthetic additive $[18,19]$. One of these peptides from hemoglobin hydrolysis, the $\alpha 137-141$ fragment (Thr-Ser-Lys-Tyr-Arg), has interesting and particular characteristics. It contains only 5 amino-acids (for a molecular weight of $653 \mathrm{Da}$ and a pI of 10.5) while the classical antimicrobial peptides are composed of 20 amino-acids or more. Moreover, this peptide is hydrophilic and without any secondary structure in contrary of classical antimicrobial peptides having hydrophobic residues and an $\alpha$-helix in their structures [15]. At last, the $\alpha 137-141$ peptide has a large antibacterial spectrum, especially against pathogenic bacteria commonly responsible for food biological alteration [20]. Two recent studies showed that this peptide has also an antioxidant activity delaying the rancidity after addition into meat [21, 22]. Consequently, this antimicrobial and antioxidant peptide is a natural promising preservative for the substitution of synthetic additives widely used to protect food during its storage and distribution [2, 21, 22].

However, the main challenge in the production of such a bioactive peptide derived from proteins is its isolation from the complex feed hydrolysate. Indeed, the variety in sizes and charges of the peptides present after hydrolysis makes its separation difficult. Nevertheless, its separation, enrichment or purification, is a necessary step to obtain a significant bioactivity [23, 24]. Using solvent for peptide extraction is one possible approach [25-27]. Nevertheless, solvents or toxic chemicals are discouraged for food application and could cause environmental problem for their recycling or the process scale-up [28]. Consequently, the methodologies involved chromatography process or liquid-liquid separation are not appropriate due to their expensive costs for production of peptide fractions, generally with no-circular economy approach. Other technics as pressure-driven processes (like ultrafiltration) are more economic and sustainable but they are not able to separate compounds with similar molecular weights due to their weak selectivity $[29,30]$. Recently, a hybrid technology, called electrodialysis with ultrafiltration membrane (EDUF), was developed to make headway in terms of high selectivity and eco-friendly separation of compounds from complex mixtures [30]. Indeed, EDUF allows the separation of molecules according to their charges (application of an electric field as driving force) and their molecular weights (cut-off of the filtration membrane). This technology showed successful results on the fractionation of hydrolysates from different sources, such as alfalfa white protein [31], soy [32] and snow crab [33]. Nonetheless, at our knowledge, no study demonstrates the influence of peptide population on the selective separation 
of one peptide from a complex hydrolysate during EDUF treatment. In this context, the aim of the present work was to study the effect of hydrolysis degree of bovine hemoglobin derived from slaughterhouse by-product on the EDUF process selectivity with a particular focus on the $\alpha 137-141$ antibacterial peptide recovery.

\section{Materials and Methods}

\section{Chemicals}

All chemicals and solvents were of analytical grade from commercial suppliers: Sigma-Aldrich (Saint-Quentin Fallavier, France) or Flandres Chimie (Villeneuve d'Ascq, France). The purified bovine hemoglobin (BH) was also supplied by Sigma-Aldrich. The ultrapure water was prepared using a Milli-Q system. The standard $\alpha 137-141$ was provided by Genecust (Luxembourg).

\section{Hydrolysate Preparation}

A stock solution was prepared by adding $15 \mathrm{~g}$ of $\mathrm{BH}$ into $100 \mathrm{~mL}$ of ultrapure water. The real $\mathrm{BH}$ concentration $\left(\mathrm{C}_{\mathrm{BH}}\right)$ was dosed with the Drabkin's method [34], after 30 min of centrifugation at $4000 \mathrm{~min}^{-1}$. After that, the stock solution was diluted to obtain a final $\mathrm{C}_{\mathrm{BH}}$ of $1 \%(\mathrm{w} / \mathrm{v})$.

The hydrolysis was carried out at $\mathrm{pH} 3.5$ and under a constant temperature of $23^{\circ} \mathrm{C}$, using the ratio enzyme/substrate $=1 / 11$ (mole/mole) [35]. The BH was digested by pepsin from porcine gastric mucosa (EC 3.4.23.1, 3200-4500 units $\mathrm{mg}^{-1}$ protein), broadly described to generate bioactive peptides from BH [8-10]. The peptic hydrolysis was stopped by addition of sodium hydroxide $(5 \mathrm{M})$ up to a final $\mathrm{pH}$ of 9 after 2.5 and $30 \mathrm{~min}, 3,10$ and $24 \mathrm{~h}$ corresponding to respective degrees of hydrolysis (DH) of 3, 5, 10, 13 and $18 \%$. The DH was assessed by the ortho-phthaldialdehyde method [36]. After hydrolysis, the hydrolysate was decolorized in order to eliminate the remaining haem since it was shown in a previous study that the presence of haem has a negative impact on the migration transfer during EDUF [37]. Removing the haem consisted to decrease slowly the $\mathrm{pH}$ at a value of 4.7 with $\mathrm{HCl}(2 \mathrm{M})$. The haem was totally precipitated and peptides were maintained in the solution after $24 \mathrm{~h}$ at room temperature. Both phases were separated by a $30 \mathrm{~min}$-centrifugation $\left(4000 \mathrm{~min}^{-1}\right)$. After this step, the hydrolysate was ready for EDUF electroseparation.

\section{Electroseparation}

\section{Electrodialysis with Ultrafiltration Membrane Equipment}

The electrodialysis cell was a MicroFlow type cell (Electrocell AB, Täby, Sweden) with an effective area of $10 \mathrm{~cm}^{2}$.
The cell configuration is displayed in Fig. 1. The use of a cationic configuration allowed the recovery of the positive charged compounds. Four closed compartments were delimited by the different membranes. In this configuration, the anionic and cationic membranes separated the $\mathrm{Na}_{2} \mathrm{SO}_{4}$ $\left(20 \mathrm{~g} \mathrm{~L}^{-1}\right)$ electrodes rinsing solution. On both sides of the ultrafiltration membrane, the cationic peptides recovery (a $2 \mathrm{~g} \mathrm{~L}^{-1} \mathrm{KCl}$ solution) and the feed compartments (a freshly prepared hydrolysate at $1 \% \mathrm{w} / \mathrm{v}$ ) were circulated. Each compartment was connected to a separate external reservoir to allow the recirculation of the solution by using centrifugal pumps (Iwaki, Marcoussis, France). The flow rate of each solution was controlled by a flowmeter (Kobold Instrumentation, Cergy-Pontoise, France). Finally, the anode/cathode voltage difference was supplied by a variable $0-30 \mathrm{~V}$ power source HQ Power PS3003 (Xantrex, Burnaby, Canada).

The ultrafiltration membrane (UF) used was a polyethersulfone (PES) with a molecular weight cut-off of $10 \mathrm{kDa}$ (HFK-131, Koch, France). The ion-exchange membranes were Neosepta cationic (CMX-SB) and anionic membrane (AMX-SB) from Astom (Tokyo, Japan).

\section{Experimental and Cleaning Protocols}

The EDUF treatment was performed during $4 \mathrm{~h}$. All the compartments contained $500 \mathrm{~mL}$ of solution $\left(\mathrm{Na}_{2} \mathrm{SO}_{4}, \mathrm{KCl}\right.$ or hydrolysate). The voltage was maintained constant $(20 \mathrm{~V})$, corresponding to an electric field of $9 \mathrm{~V} \mathrm{~cm}^{-1}$. The circulation flows were of $18 \mathrm{~L} \mathrm{~h}^{-1}$ for the electrode solution $\left(\mathrm{Na}_{2} \mathrm{SO}_{4}\right)$ and $12 \mathrm{~L} \mathrm{~h}^{-1}$ for the cationic peptides recovery $(\mathrm{KCl})$ and the feed compartments (hydrolysate). Every $30 \mathrm{~min}$, samples were recovered for further RP-HPLC and LC-MS analyses. Moreover, the $\mathrm{pH}$ and the conductivity $\left(\mathrm{mS} . \mathrm{cm}^{-1}\right)$ were measured

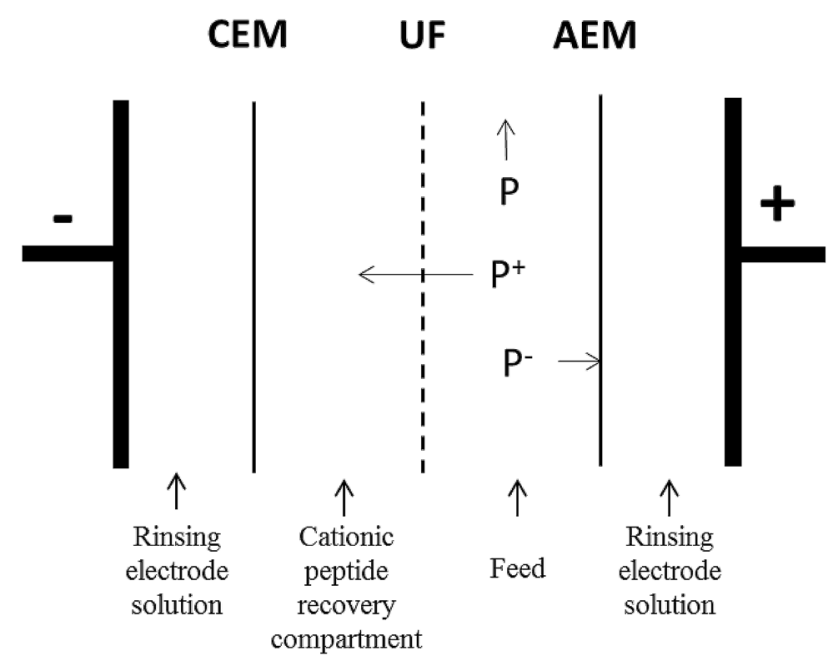

Fig. 1 Electrodialytic cell with cationic configuration. $C E M$ cationexchange membrane, $A E M$ anion-exchange membrane, $U F$ ultrafiltration membrane 
within the recovery and hydrolysate compartments. The demineralization rate (DR, in \%) was calculated by the following Eq. (1):

$D R=\frac{\text { Conductivity }_{t=0}}{\text { Conductivity }_{t}} \times 100$

where Conductivity ${ }_{t=0}\left(\mathrm{mS} \mathrm{cm}^{-1}\right)$ is the conductivity measured at the beginning of the experiment before current application and Conductivity $\left(\mathrm{mS} \mathrm{cm}^{-1}\right)$ is the conductivity at a given time $t$.

The current intensity (A) and the voltage (V) were also recorded. For the five selected hydrolysates (DH of 3, 5, 10, 13 and $18 \%$ ), each electroseparation was carried out in triplicate. All the membranes in the EDUF cell were changed for a new tested DH.

After each repetition, the EDUF was cleaned to remove a potential deposit in the apparatus, as previously described [31]: water (5 min), a NaOH solution $(0.1 \mathrm{M}, 30 \mathrm{~min})$, water (5 min) and then a $\mathrm{HCl}$ solution $(0.1 \mathrm{M}, 20 \mathrm{~min})$ were circulated in the system. Finally, the neutral $\mathrm{pH}$ was recovered in all the compartments by rinsing with ultrapure water.

\section{Analyses}

\section{$\mathrm{pH}$}

The $\mathrm{pH}$ was measured in the feed and $\mathrm{KCl}$ solution every 30 min during the EDUF treatment with a $\mathrm{pH}$-meter Model SP20 provided by Thermo Fisher Scientific (Villebon-surYvette, France).

\section{Conductivity}

The conductivity was measured in the feed and $\mathrm{KCl}$ solution every 30 min during the EDUF treatment with a conductimeter 4520 (Jenway, France).

\section{Current Intensity}

The current intensity was directly read on the power supply and recorded every 30 min during the EDUF treatment.

\section{Apparent System Resistance}

The apparent system resistance was determined using the Ohm's law. The current intensity and the voltage were monitored during the EDUF treatment as above-mentioned. The apparent system resistance was calculated according to the following Eq. (2):

$R=\frac{U}{I}$ where $R$ is the global system resistance $(\Omega), I$ the current intensity (A) and $U$ the voltage applied between the electrodes of the EDUF cell (V).

\section{RP-HPLC analyses, Total Peptide Concentration and a137- 141 Quantification}

The liquid chromatographic system consisted of a waters $600 \mathrm{E}$ automated gradient controller pump module, a Waters Wisp 717 automatic sampling device and a Waters 996 photodiode array detector. Spectral and chromatographic data were stored on an NEC image 466 computer. Millennium software was used to plot, acquire and analyze chromatographic data. All the chromatographic processes were performed with a Vydac $\mathrm{C}_{4}$ column $(250 \mathrm{~mm} \times 4.6 \mathrm{~mm}$, internal diameter). The mobile phases were ultrapure water/ trifluoroacetic acid $(1000: 1, \mathrm{v} / \mathrm{v})$ as eluent $\mathrm{A}$, and acetonitrile/ultrapure water/trifluoroacetic acid (600:400:1, v/v/v) as eluent B. Samples were filtered through $0.20 \mu \mathrm{m}$ filters and then injected. Online UV absorbance scans were performed between 200 and $390 \mathrm{~nm}$ at a rate of one spectrum per second with a resolution of $1.2 \mathrm{~nm}$. Chromatographic analyses were completed with Millenium software [11,38]. The volume of injection was $10 \mu \mathrm{L}$ for the total hydrolysate and $100 \mu \mathrm{L}$ for the samples from the recovery compartment. The flow rate was $0.6 \mathrm{~mL} \mathrm{~min}{ }^{-1}$. The gradient applied was $100 \%(\mathrm{v} / \mathrm{v})$ A over $5 \mathrm{~min}, 0-67 \%(\mathrm{v} / \mathrm{v})$ B over $30 \mathrm{~min}$, then $67-87 \%$ (v/v) B over 35 min.

The total peptide concentration of each sample from bovine hemoglobin hydrolysate was evaluated by measuring the total area corresponding to the peptides $\left(A_{t o t}\right)$ using the Millennium software and correlated with the initial $\mathrm{C}_{\mathrm{BH}}$ measured by using the Drabkin's method [34].

To identify and quantify rapidly the $\alpha 137-141$ peptide within the hydrolysate, the spectral comparison and assessment of peak purity were carried out by UV-spectral comparison as described previously [11,38]. The $\alpha 137-141$ retention time was about $4 \mathrm{~min}$. A standard curve was established by injections of standard $\alpha 137-141$ at concentrations ranging between 0 and $1 \mathrm{mg} \mathrm{mL}^{-1}$. The areas under the peak were taken from a chromatographic profile at $215 \mathrm{~nm}$ and allowed to quantify the $\alpha 137-141$ peptide present in sample by using the following Eq. (3) $\left(\mathrm{R}^{2}=0.999\right)$ :

$C_{\alpha 137-141}=4419.6 . A_{\alpha 137-141}$

where $C_{\alpha 137-141}$ being the $\alpha 137-141$ concentration $\left(\mathrm{mg} \mathrm{L}^{-1}\right)$ and $A_{\alpha 137-141}$ being the area peak $(\mu \mathrm{V} \mathrm{s})$.

The $\alpha 137-141$ purity (\%) was assessed by (4):

$\frac{A_{\alpha 137-141}}{A_{\text {total }}} \times 100$ 
where $A_{\alpha 137-141}$ being the area peak $(\mu \mathrm{V} \mathrm{s})$ and $A_{\text {total }}(\mu \mathrm{V} \mathrm{s})$ being the total peptide area of chromatogram.

\section{Transport Rate and Enrichment Factor}

The transport rate was expressed in $\mathrm{g} \mathrm{m}^{-2} \mathrm{~h}^{-1}$ from the previous total peptide concentration determined by HPLC considering the membrane surface area $\left(\mathrm{m}^{2}\right)$ and the EDUF treatment duration $(\mathrm{h})$.

The peptide enrichment factor (EF) was calculated by Eq. (5):

$E F=\frac{\text { Peptidepurity }_{\text {inKClsolution }}}{\text { Peptidepurity }_{\text {ininitialfeed }}}$

\section{Mass Spectrometry Analyses}

The LC-MS analysis were performed on a UFLC-XR device (Shimadzu, Japan) coupled to a QTRAP ${ }^{\circledR} 5500$ MS/MS hybrid system triple quadrupole/linear ion trap mass spectrometer (AB Sciex, Foster City, CA, USA) equipped with a Turbo VTM ion source. Instrument control and data acquisition were performed using the Analyst 1.5.2 software. The RPLC separation was carried out on the same column used for the RP-HPLC analyses ( $\$ 2.4 .5$ ). The elution was performed with the same gradient, previously described, using formic acid $(0.1 \%)$ instead of trifluoroacetic acid $(0.1 \%)$ for the RP-HPLC analyses. MS analysis was carried out in positive ionization mode using an ion spray voltage of $5500 \mathrm{~V}$. The nebulizer gas (air) and the curtain gas (nitrogen) flows were set at $30 \mathrm{psi}$. The Turbo VTM ion source was set at $550^{\circ} \mathrm{C}$ with the auxiliary gas flow (air) set at $50 \mathrm{psi}$. The MS/MS analyses were completed with the BioAnalyst 1.5.1 and Peaks 7 softwares.

\section{Statistical Analyses}

Mean values for various parameters ( $\alpha 137-141$ concentration, $\alpha 137-141$ purity, $\alpha 137-141$ transport rate, $\alpha 137-141$ enrichment factor) were subjected to one-way analyses of variance. Statistical significance was declared at the $p$ value $\leq 0.05$.

\section{Results}

\section{Characterization of the Whole Initial Hydrolysates}

The RP-HPLC profiles of the five initial hydrolysates were presented in Fig. 2. It appeared from the chromatograms that at DH 3\%, the hemoglobin protein was not totally hydrolyzed by the pepsin and the $\alpha$ - and $\beta$-chains were still present in the hydrolysate (retention time from 37 to $42 \mathrm{~min}$ ). At this $\mathrm{DH}$, a first peptide population was mainly present with a retention time from 22 to $36 \mathrm{~min}$. This peptide population was composed of intermediate peptides with high molecular weights, formed of 20 or more aminoacids. At DH 5\%, the $\alpha$ - and $\beta$-chains were totally digested (no peak present between 37 and $42 \mathrm{~min}$ ) and the intermediate peptide population decreased in intensity (from 31 to $36 \mathrm{~min}$ ) to lead to smaller peptides (from 20 to $30 \mathrm{~min}$ ). The population between 5 to $8 \mathrm{~min}$ and 15 to $20 \mathrm{~min}$ of retention time increased in intensity. This population was essentially composed by "final peptides" which had low molecular weights and are generally composed by 5 to 10 amino-acids. This population increased with the $\mathrm{DH}$ evolution and was more present at high $\mathrm{DH}$, as observed for DHs of 10, 13 and 18\%. In the opposite, the intermediate peptide population (from 31 to $36 \mathrm{~min}$ ) decreased when the DH increased. At the DH of $18 \%$, this population was totally cleaved in smaller peptides. Therefore, in the conditions of hydrolysis carried out $\left(\mathrm{pH} 3.5,23{ }^{\circ} \mathrm{C}\right.$, ratio enzyme/substrate $=1 / 11$ ), the enzymatic mechanism was of "zipper" type [35], as described for the first time in 1952 [39]. It allowed the generation of different peptide populations from a substrate according to the hydrolysis duration. Briefly, the enzyme catalytic speed is high at the proteolysis beginning creating peptides with high molecular weights. During hydrolysis, these generated peptides become new substrates for the enzyme and can be hydrolyzed into smaller peptides. When the hydrolysis time is high, peptide population is composed by peptides with small molecular weights.

The identification of all peptides present was performed by LC-MS/MS. The number and the repartition by massranges of the peptides are displayed in Table 1. So, the number of peptides during the hydrolysis varied from 78 to 162 , with a progressive accumulation of low molecular weights $(<1000 \mathrm{Da}$ ) from 29 (at a DH of 3\%) to 121 (at a DH of $18 \%)$.

Recently, the hydrolysis kinetics of bovine or porcine hemoglobin by pepsin have been studied for hydrolysis

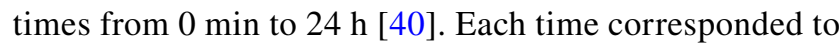
a different $\mathrm{DH}$ with a new and different peptide population. These peptide populations were various in terms of present peptides. After a hydrolysis of $2.5 \mathrm{~min}$, the $\alpha$ and $\beta$ chains of hemoglobin disappeared in favor of a large mass of peptides eluted before the hem. Moreover, when the hydrolysis degree increased, the peptide molecular weights decreased corresponding to the cleavage from hydrophobic high molecular weight peptides to hydrophilic low molecular weight peptides. 

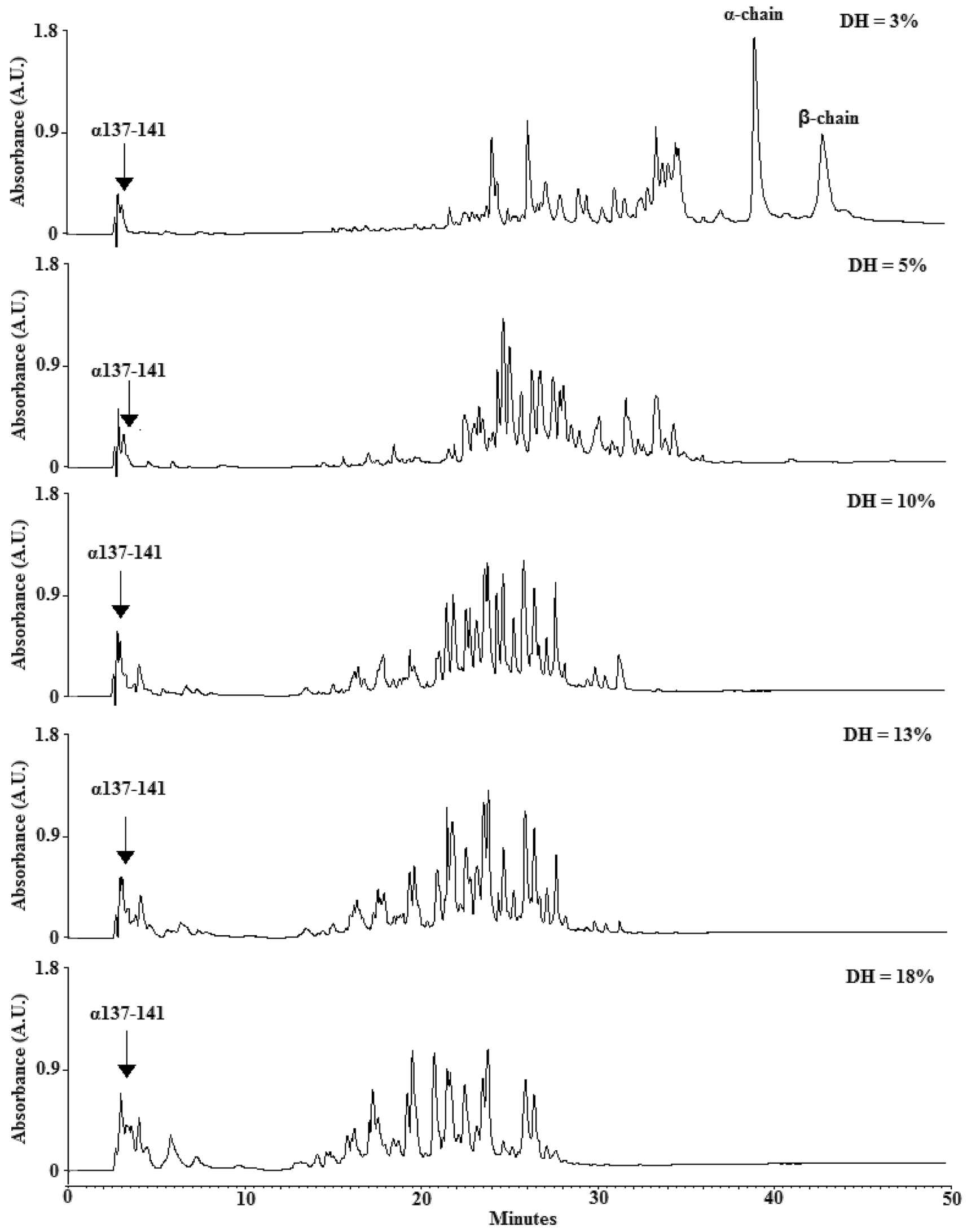

Fig. 2 RP-HPLC profiles of whole hydrolysates at five different hydrolysis degrees. Peptide population were essentially composed by peptides with high molecular weights (high retention times) at short hydrolysis times (weak DH). In the opposite, peptide population were essentially composed by peptides with small molecular weights (low retention times) at high hydrolysis times (high DH) 
Table 1 Mass-range repartitions (Da) of the peptides depending on the hydrolysis degree of bovine hemoglobin

\begin{tabular}{llrrrrr}
\hline & DH (\%) & \multicolumn{1}{c}{5} & \multicolumn{1}{c}{5} & 10 & 13 & 18 \\
\hline Mass-ranges (Da) & $<500$ & 1 & 8 & 9 & 11 & 11 \\
& 501 to 1000 & 28 & 43 & 75 & 91 & 110 \\
& 1001 to 1500 & 26 & 29 & 27 & 32 & 27 \\
& 1501 to 2000 & 17 & 16 & 19 & 19 & 14 \\
& $>2001$ & 6 & 5 & 2 & 2 & 0 \\
& Total & 78 & 101 & 132 & 155 & 162 \\
\hline
\end{tabular}

When the DH increased, the total peptide number in the hydrolysate increased too with an increase of small peptide number

\section{Electrodialytic Paramaters Evolution}

\section{Conductivity, Demineralization Rate and pH}

For the hydrolysate compartment, the conductivity as well as the $\mathrm{pH}$ did not evolve significantly during the EDUF treatment whatever the tested DH (data not shown) with an averaged value of $9 \mathrm{mS} \mathrm{cm}^{-1}$ and a $\mathrm{pH}$ of 4.7 which was the initial $\mathrm{pH}$ of the decolorized hydrolysate. On the opposite, the conductivity of the cationic peptides recovery compartment decreased throughout the EDUF treatment and that whatever the tested DH (Fig. 3). This conductivity decrease was in accordance with the electrodialytic cell configuration used. Indeed, the $\mathrm{K}^{+}$migrated from the $\mathrm{KCl}$ solution to the electrode solution through the cation-exchange membrane and the $\mathrm{Cl}^{-}$migrated from the recovery compartment to the feed through the UF membrane. However, if the initial conductivity was the same for all DHs (about $3 \mathrm{mS} \mathrm{cm}^{-1}$ ), the final conductivity and its behavior during the experiment were not similar: the conductivity decreased, or demineralization rate increased as a function of DH decrease. Consequently, the highest final demineralization rates were observed for hydrolysates produced at DHs of 3 and 5\% (89.40 \pm 0.83 and $87.25 \pm 4.09 \%$, respectively), while at a $\mathrm{DH}$ of $18 \%$ the resulting hydrolysate presented the lowest demineralization rate after $4 \mathrm{~h}$ of treatment: $18 \% \mathrm{DH}$ demineralization rate was of $49.00 \pm 2.01 \%$, close to DH of $13 \%(54.32 \pm 1.68 \%)$. Moreover, for all tested DHs, a two-steps demineralization was observed: a first rapid demineralization period followed by a second slower demineralization step. This two-steps demineralization did not appear at the same time according to the DH. Hence, for DHs of 10, 13 and $18 \%$, the conductivity decreased quickly during the first 30 min with a mean slope of -1.48 , to thereafter slowed down with a mean demineralization slope of -0.26 . For DHs of $3 \%$ and $5 \%$, the second step began only after respectively about $1 \mathrm{~h}$ and $0.5 \mathrm{~h}$ of experiment with respective slopes of -0.48 and -0.56 . This two-steps conductivity decrease was due to the fact that the limiting current density was reached and overpassed during the process. This phenomenon was broadly described in previous papers [31, 41, 42]. Overpassing the limiting current density induced the phenomenon of water-splitting which could occur on the feed-side of the anion-exchange membrane and/or the recovery-side of the cation-exchange membrane [42]. In our case, water splitting occurred mainly at the interface of the cation-exchange membrane since the $\mathrm{pH}$ in the feed compartment was stable all along the treatment, which was not the case for the recovery compartment.
Fig. 3 Evolution of conductivities into the recovery compartment during the EDUF treatment in the different conditions of bovine hemoglobin degree of hydrolysis. The $\mathrm{KCl}$ solution conductivities decreased all along the EDUF treatment with an important first-step decrease during the first $30 \mathrm{~min}$, regardless the used DH

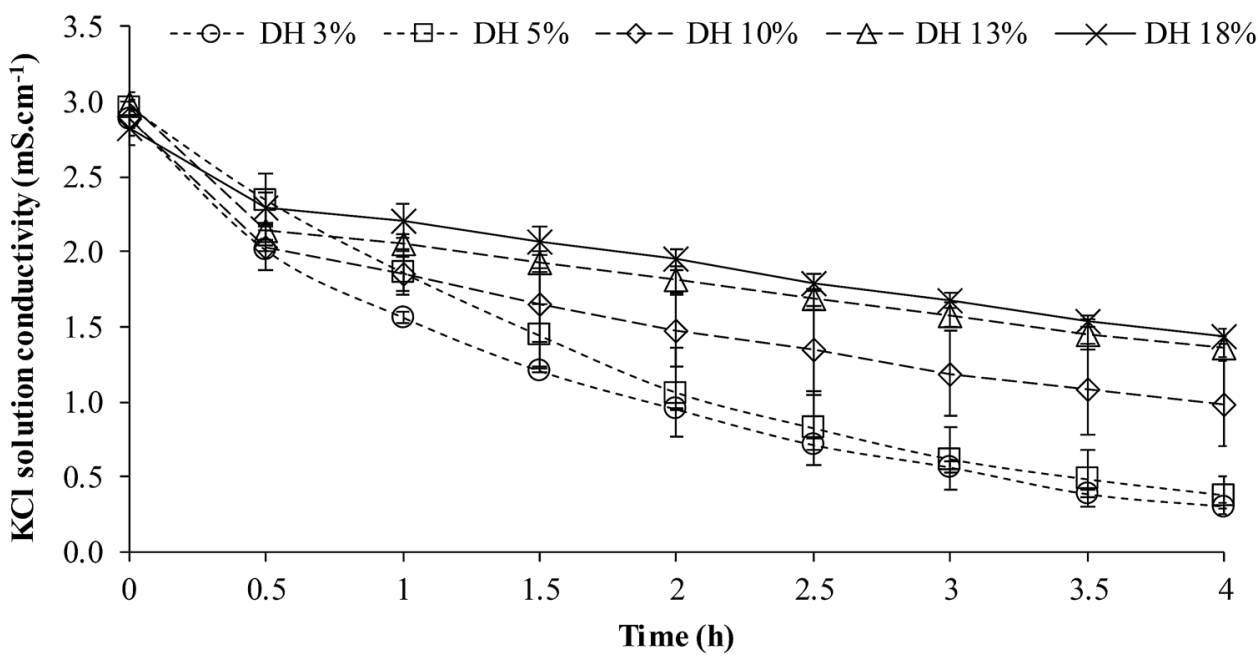


Indeed, the release of $\mathrm{OH}^{-}$at the interface of the CEM into the peptide recovery compartment induced a fast increase of its $\mathrm{pH}$ : after about $30 \mathrm{~min}$ of treatment, for DHs higher or equal to $5 \%$, the $\mathrm{pH}$ of the recovery compartment was up to 10 for an initial value of about 5 while at $3 \% \mathrm{DH}$, the $\mathrm{pH}$ increased to 10 after about $1 \mathrm{~h}$ (data not shown). These results are quite in accordance with the appearance of the second demineralization step. Indeed, by generating $\mathrm{OH}^{-}$species in the peptide recovery compartment, the $\mathrm{pH}$ of the solution will increase and also its conductivity. In fact, the generation of $\mathrm{OH}^{-}$entering the peptide recovery compartment has compensated for the migration of $\mathrm{K}^{+}$and $\mathrm{Cl}^{-}$leaving this compartment: the electrical conductivity of $\mathrm{OH}^{-}$is largely higher than the ones of $\mathrm{Cl}^{-}$and $\mathrm{K}^{+}$[42], so the generation of $\mathrm{OH}^{-}$in the solution has slowed down the decrease in conductivity due to the leaving of $\mathrm{K}^{+}$and $\mathrm{Cl}^{-}$. This explained that the conductivity decrease of the $3 \% \mathrm{DH}$ was more pronounced in comparison with other DHs since the limiting current density reaching and so the generation of $\mathrm{OH}^{-}$were delayed. This also applied for the $5 \% \mathrm{DH}$ but at a lower extent.

The difference in appearance times according to the DH could be explained by the peptide population diversity and/or the membrane fouling. Indeed, the elevation of DH increased the number of peptides able to migrate as well as decreased their size facilitating their potential migration. So, the ionic migration from the recovery compartment could be slowed down more rapidly, because the peptides in the feedside of the UF membrane were in competition with the ions in counter-current flow (i.e. from recovery to feed). Concerning membrane fouling, the fact that small peptides were more numerous as seen on Fig. 2 and Table 1, these peptides would have probably interacted or increased the possibilities of interactions with the membranes, probably the UF membrane. These results showed that the most important ionic migration was observed at the low DHs. However, it is suggested that for the peptide migration, the most appropriate $\mathrm{DH}$ would be the hydrolysate at the $\mathrm{DH}$ of $5 \%$, i.e. the lowest DH without the undigested subunits of hemoglobin.

\section{Apparent System Resistance}

With a $20 \mathrm{~V}$ constant voltage applied (U) during the EDUF treatment, the intensity (I) decreased from 0 to $4 \mathrm{~h}$. Hence, according to the Ohm's law, the initial resistances of the system (R) were similar for all tested DHs and increased all along the process duration (data not shown), from around $64.5 \Omega$ at the beginning to $250 \Omega$ at the end, as presented on Fig. 4. However, the apparent system resistance increased more rapidly at higher DHs and resistances of $142.86 \pm 10.20$ $\Omega$ were observed for DH of 13 and $18 \%$ after $1 \mathrm{~h}$ of treatment versus $80.00 \pm 3.20 \Omega$ at a DH of $3 \%$ and $86.96 \pm 3.78 \Omega$ at $5 \%$. These results confirmed the previous results obtained for conductivity and concluding to the appearance of water splitting. Due to the resistance increase in the EDUF cell, the limiting current density was reached in advance at high DHs, generating $\mathrm{OH}^{-}$at the CEM interface in contact with the recovery compartment. These results would be probably due to the formation of a fouling on the ultrafiltration membrane side in contact with the hydrolysate. As mentioned previously, the peptide population diversity as well as their higher number and lower sizes at higher DHs would have probably interacted or increased the possibilities of interactions with the membranes, increasing consequently the global resistance of the cell and the generation of $\mathrm{OH}^{-}$at the CEM. It was reported in the literature that the interaction peptide-peptide and peptide-membrane can affect the transfer ability of the membrane [43]. Moreover, according to previous works [32], the polyethersulfone (PES) ultrafiltration membrane acquired more negative charges at $\mathrm{pH}$ measured during the EDUF treatment (about 10) and with this EDUF configuration. This would explain the increase
Fig. 4 Evolution of apparent system resistance during the EDUF treatment in the different conditions of bovine hemoglobin degree of hydrolysis. The apparent system resistance during the EDUF treatment increased during all experiments regardless used $\mathrm{DH}$

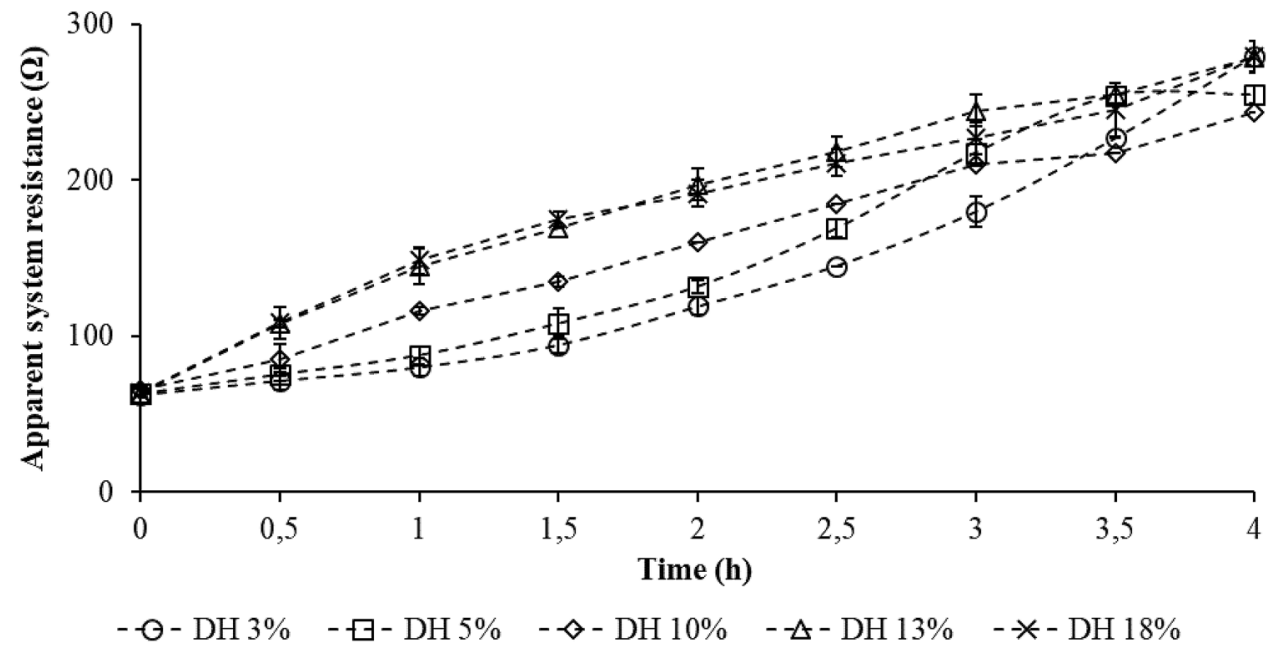


in membrane fouling with a DH elevation by electrostatic interactions of the peptides charged positively [32, 44, 45].

\section{Effect of Hydrolysis Degree on the Total Peptide Migration}

Figure 5 shows the RP-HPLC profiles of the recovery compartment after $4 \mathrm{~h}$ of EDUF treatment for the hydrolysates at five different DHs. At DH 3\%, few peptide peaks were clearly identified according to their low intensities on the chromatogram. At DH 5\%, a first population appeared from 14 to $17 \mathrm{~min}$ and a second one between 22 and $30 \mathrm{~min}$, mainly corresponding to the retention time of the intermediate peptides. From DH 5\% to 18\%, the intensities of peptide peaks between 15 to $30 \mathrm{~min}$ increased and the number of peptide peaks increased too.

Moreover, Fig. 6 presents the evolution of recovered total peptide concentration during the $4 \mathrm{~h}$ of experiment. The recovered concentration for DH $3 \%$ showed a linear trend with a plateau reached rapidly ( $30 \mathrm{~min})$ at a total peptide concentration of $0.97 \pm 0.14 \mathrm{mg} \mathrm{L}^{-1}$. The evolution of recovered concentrations for DH 5 and $10 \%$ were quite similar with total peptide concentrations of $17.01 \pm 2.41$ and $13.09 \pm 4.75 \mathrm{mg} \mathrm{L}^{-1}$, respectively. The DHs of 13 and $18 \%$ showed a trend similar with a final peptide concentration of $68.48 \pm 1.62$ and $67.43 \pm 5.36 \mathrm{mg} \mathrm{L}^{-1}$, respectively. For the hydrolysate with a DH of $3 \%$, the peptide migration was the least effective. The peptide transfer towards the $\mathrm{KCl}$ solution was slowed down by the small quantity of peptides able to migrate due to the low hydrolysis degree of the protein. Indeed, the identification of peptides by LC-MS/MS (Table 2) showed that only 4 peptides out of 78 in the whole hydrolysate are recovered in the $\mathrm{KCl}$ solution and 3 of these 4 peptides had a mass ranging from 501 to $1000 \mathrm{Da}$. Hence, when the DH increased, the recovered peptide population increased too. The maximal number of recovered peptides was recorded for the hydrolysate at a DH of $18 \%$. In this condition, 29 peptides migrated through the ultrafiltration membrane with masses ranging from 501 to $1000 \mathrm{Da}$. In addition, the highest concentrations of peptides in the recovery compartment were observed for hydrolysates at DH of 13 and $18 \%$, with respective peptide concentrations of $68.48 \pm 1.62$ and $67.43 \pm 5.36 \mathrm{mg} \mathrm{L}^{-1}$. From Table 2, it also appeared that peptides with a mass between 501 and 1000 Da migrated more than the other peptides. According to Table 1, the first reason was that the peptides in this mass-range were the more numerous and their number increased with an increase in DH. Secondly, the digestion of the peptides with high molecular weights (>2000 Da) induced their progressive disappearance during the hydrolysis. These results were in accordance to a recent study which showed that when the DH increased, the peptide number increased too [40]. So, the small peptides could interact less with the high peptides and then migrate more through the ultrafiltration membrane at an advanced DH. On the other hand, the number of peptides able to migrate were higher than at low DH. So, the migration of a given small peptide $(<1000 \mathrm{Da})$ would be more competitive at a high DH due to the number of peptides generated and present in the mixture.

\section{Effect of the Hydrolysis Degree on the Antibacterial a137-141 Peptide Recovery}

As observed on Fig. 5 for the peptide recovery chromatograms, at a DH of 3\%, the $\alpha 137-141$ peptide was not present (retention time of $5 \mathrm{~min}$ ). At DH 5\%, the $\alpha 137-141$ peptide started to be present ( $5 \mathrm{~min}$ ). From DH 5\% to $18 \%$, the $\alpha 137-141$ peptide peak showed a decrease in the recovery compartment when the hydrolysate DH increased.

Table 3 details the concentration, purity and transport rate for the $\alpha 137-141$ peptide in the different conditions of hydrolysate DH. Due to the "zipper" mechanism and the fact that the $\alpha 137-141$ (retention time of about 4 min on Fig. 2) was a final peptide in these hydrolysis conditions [35], its concentration in the hydrolysate increased over the hydrolysis time. The final $\alpha 137-141$ concentration in the peptide recovery compartment for the hydrolysate with a DH of 3\% was the poorest: no significant $\alpha 137-141$ concentration was measured at the end of the EDUF treatment. For DHs higher that $3 \%$, the $\alpha 137-141$ transfer through the ultrafiltration membrane was the least effective with the hydrolysate at a DH of $18 \%\left(0.17 \pm 0.04 \mathrm{~g} \mathrm{~m}^{-2} \mathrm{~h}^{-1}\right)$. Consequently, no significant enrichment factor was observed at a DH of $18 \%$ although the $\alpha 137-141$ concentration was higher in the whole hydrolysate. The hydrolysate with a DH of 5\% presented the higher transport rate of $\alpha 137-141$ peptide during the $4 \mathrm{~h}$ of EDUF treatment with a value of $0.67 \pm 0.04 \mathrm{~g} \mathrm{~m}^{-2} \mathrm{~h}^{-1}$, which corresponded to a concentration factor of fourfold higher than at DH of $18 \%$. Hence, the observed enrichment factor decreased with an increase in DH.

Concerning the purity of the $\alpha 137-141$ peptide into the recovery compartment, it was up to $10.27 \pm 0.04 \%$ at a DH of 5\%. This value of $\alpha 137-141$ purity was eightfold higher than the value at a DH of $18 \%(1.20 \pm 0.04 \%)$ : an enrichment factor of about 13 was obtained at a DH of 5\%. To explain the best migration of $\alpha 137-141$ at a DH of 5\%, the evolution of its concentration into the recovery compartment was followed during the $4 \mathrm{~h}$ of experiment (Fig. 7). At the end of EDUF treatment, the highest $\alpha 137-141$ concentration into the recovery compartment was obtained with the hydrolysate at a DH of $5 \%\left(5.33 \pm 0.34 \mathrm{mg} \mathrm{L}^{-1}\right)$. Moreover, its evolution was the most linear compared to the recoveries with the other DH. This behavior was reflected by the competition with other peptides with similar mass-range. Indeed, the 


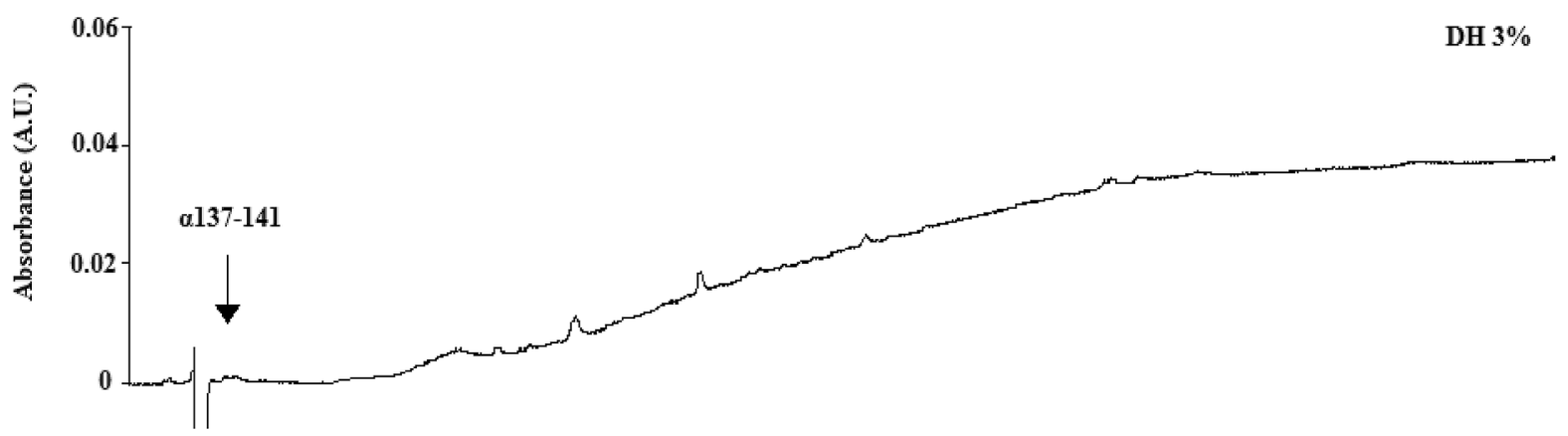

DH $5 \%$
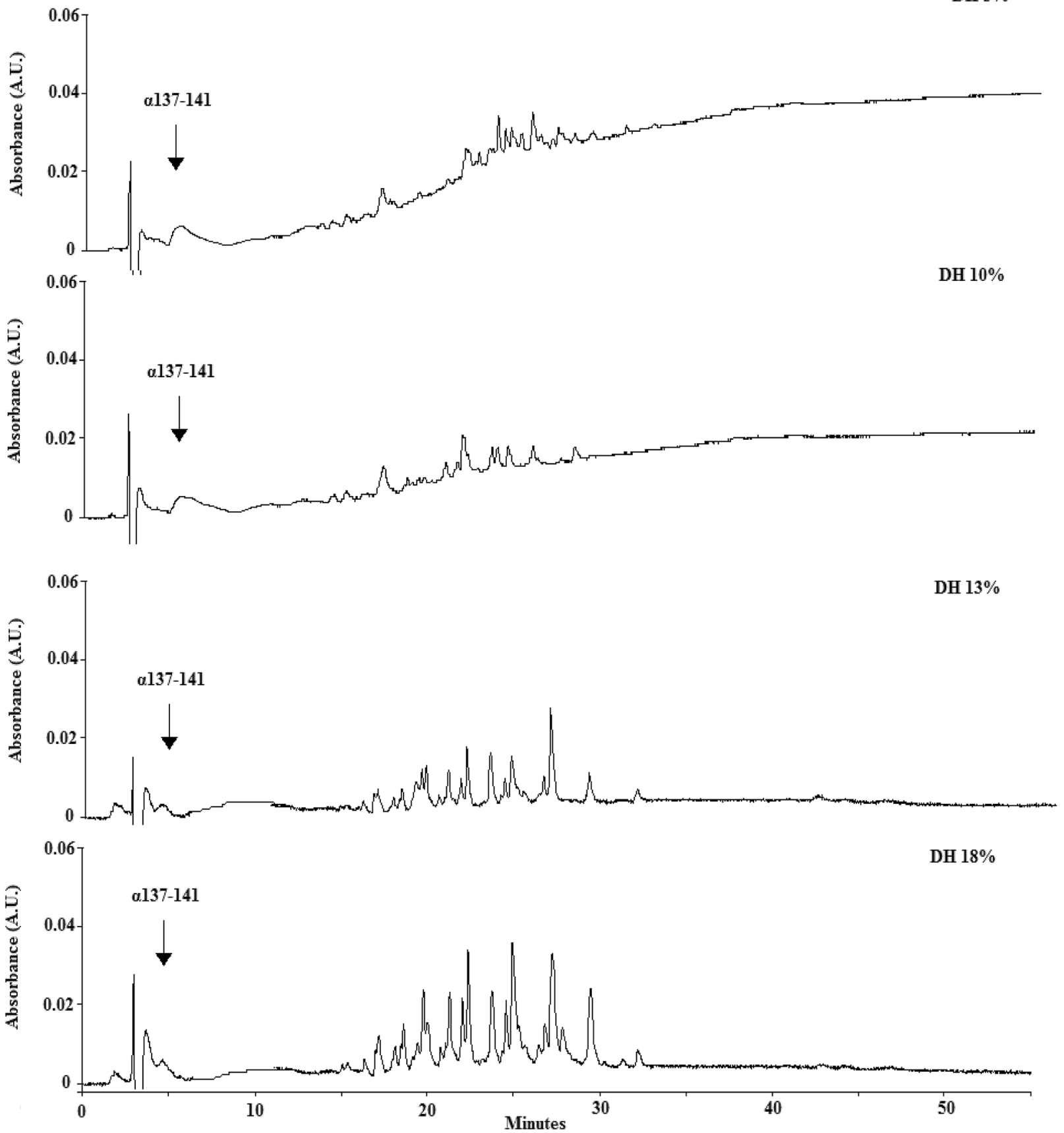

Fig. 5 RP-HPLC profiles of $\mathrm{KCl}$ solution after $4 \mathrm{~h}$ of EDUF treatment in the different conditions of bovine hemoglobin degree of hydrolysis. When the DH is high, more peptides are present in the recovery compartment 
Fig. 6 Evolution of the total peptide concentration in the $\mathrm{KCl}$ solution during the EDUF treatment in the different conditions of bovine hemoglobin degree of hydrolysis. The total peptide concentration in the $\mathrm{KCl}$ increased with the $\mathrm{DH}$ increase

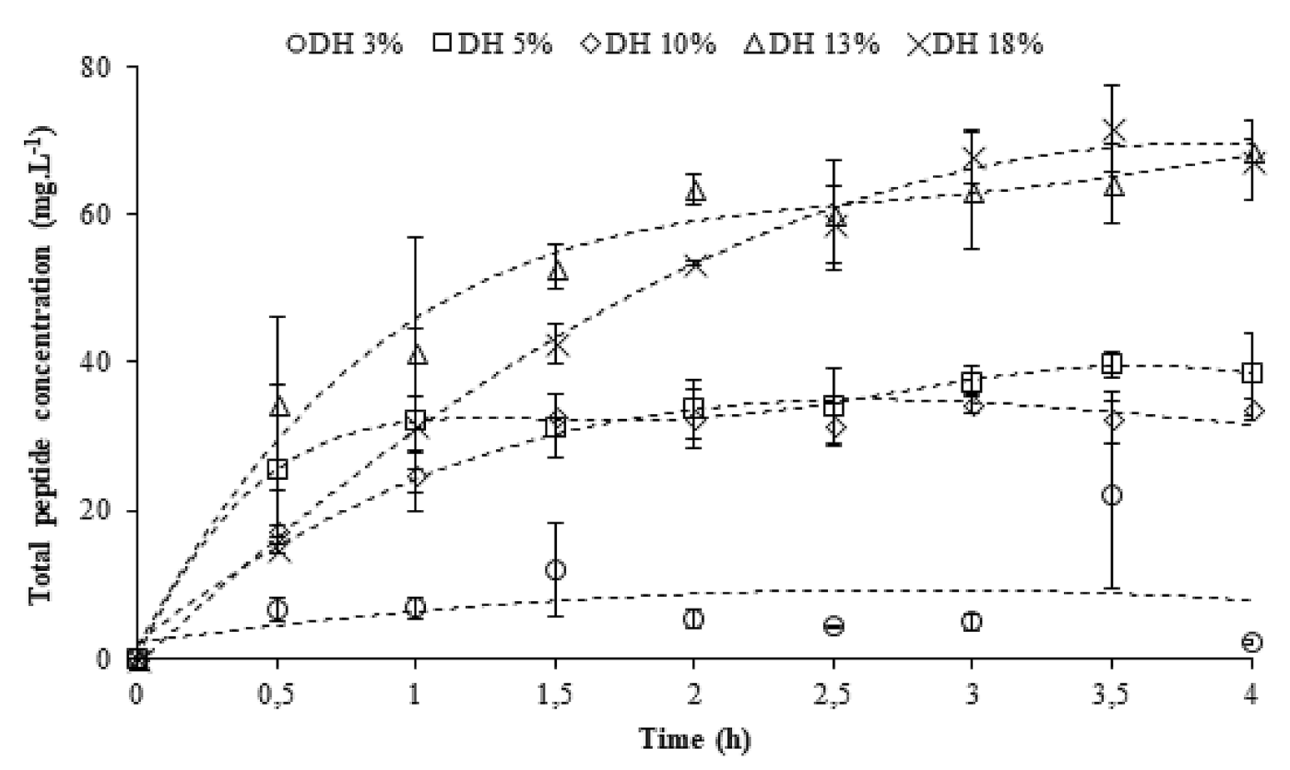

\begin{tabular}{lllrrrr}
\hline & DH (\%) & 3 & 5 & 10 & 13 & 18 \\
\hline Mass-ranges (Da) & $<500$ & 0 & 1 & 2 & 1 & 0 \\
& 501 to 1000 & 3 & 10 & 9 & 9 & 16 \\
& 1001 to 1500 & 0 & 5 & 3 & 3 & 10 \\
& 1501 to 2000 & 1 & 0 & 3 & 4 & 3 \\
& $>2001$ & 0 & 0 & 0 & 0 & 0 \\
& Total & 4 & 16 & 17 & 17 & 29 \\
\hline
\end{tabular}

When the DH increased, the recovered peptide population increased too with an increase of small recov-

ered peptides
Table 2 Mass-ranges repartitions $(\mathrm{Da})$ of the recovered peptides into the permeate solution after $4 \mathrm{~h}$ of EDUF treatment in the different conditions of bovine hemoglobin degree of hydrolysis bovine hemoglobin

Table 3 a137-141 migration after $4 \mathrm{~h}$ of EDUF treatment in the different conditions of bovine hemoglobin degree of hydrolysis

\begin{tabular}{lccccc}
\hline $\mathrm{DH}(\%)$ & 3 & 5 & 10 & 13 & 18 \\
\hline $\mathrm{C}_{\alpha 137-141}$ (hydrolysate) $\left(\mathrm{mg} \mathrm{L}^{-1}\right)$ & $36.85 \pm 5.53 \mathrm{a}$ & $74.10 \pm 9.90 \mathrm{~b}$ & $81.28 \pm 11.70 \mathrm{~b}$ & $85.32 \pm 11.78 \mathrm{bc}$ & $98.91 \pm 11.93 \mathrm{c}$ \\
$\mathrm{C}_{\alpha 137-141}$ (permeate) $\left(\mathrm{mg} \mathrm{L}^{-1}\right)$ & $0.00 \pm 0.00 \mathrm{a}$ & $5.33 \pm 0.34 \mathrm{~b}$ & $3.43 \pm 1.32 \mathrm{c}$ & $4.64 \pm 0.44 \mathrm{c}$ & $1.34 \pm 0.17 \mathrm{~d}$ \\
$\alpha 137-141$ purity (hydrolysate) $(\%)$ & $0.37 \pm 0.05 \mathrm{a}$ & $0.74 \pm 0.10 \mathrm{~b}$ & $0.81 \pm 0.12 \mathrm{bc}$ & $0.85 \pm 0.12 \mathrm{bc}$ & $0.99 \pm 0.12 \mathrm{c}$ \\
$\alpha 137-141$ purity (permeate) $(\%)$ & $0.00 \pm 0.00 \mathrm{a}$ & $10.27 \pm 0.96 \mathrm{~b}$ & $6.61 \pm 2.34 \mathrm{c}$ & $4.25 \pm 0.42 \mathrm{~cd}$ & $1.20 \pm 0.14 \mathrm{~d}$ \\
$\alpha 137-141$ transport rate $\left(\mathrm{g} \mathrm{m}^{-2} \mathrm{~h}^{-1}\right)$ & $0.00 \pm 0.00 \mathrm{a}$ & $0.67 \pm 0.04 \mathrm{~b}$ & $0.43 \pm 0.17 \mathrm{c}$ & $0.58 \pm 0.06 \mathrm{~d}$ & $0.17 \pm 0.02 \mathrm{e}$ \\
Enrichment factor & $0.00 \pm 0.00 \mathrm{a}$ & $13.86 \pm 1.30 \mathrm{~b}$ & $8.13 \pm 2.88 \mathrm{c}$ & $4.98 \pm 0.50 \mathrm{~d}$ & $1.21 \pm 0.15 \mathrm{e}$ \\
\hline
\end{tabular}

Means not sharing the same letters (a-e) within a row are significantly different $(p<0.05)$

The best enrichment factor and purity for the $\alpha 137-141$ is recovered the DH of $5 \%$

more the DH increased, the more the peptides from 500 to $1000 \mathrm{Da}$ increased in the whole hydrolysate.

So, these data demonstrated that the peptide population had a strong effect on the $\alpha 137-141$ selective separation. Indeed, the $\alpha 137-141$ transfer through the ultrafiltration membrane was less effective in the presence of numerous small peptides (from 0 to $1000 \mathrm{Da}$ ). According to these results, the most appropriate $\mathrm{DH}$ is of $5 \%$ to separate selectively the antibacterial $\alpha 137-141$ peptide. Indeed, this hydrolysate has the smaller population of small peptides ( $<1000 \mathrm{Da})$, after the hydrolysate at $\mathrm{DH}$ of $3 \%$ but this last one contains undigested sub-units of hemoglobin. 
Fig. 7 Evolution of the

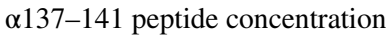
in the $\mathrm{KCl}$ solution during the EDUF treatment in the different conditions of bovine hemoglobin degree of hydrolysis. The $\alpha 137-141$ concentration increased with the DH increase with an optimum at the $\mathrm{DH}$ of $5 \%$. After this DH, the $\alpha 137-$ 141 concentration decreased

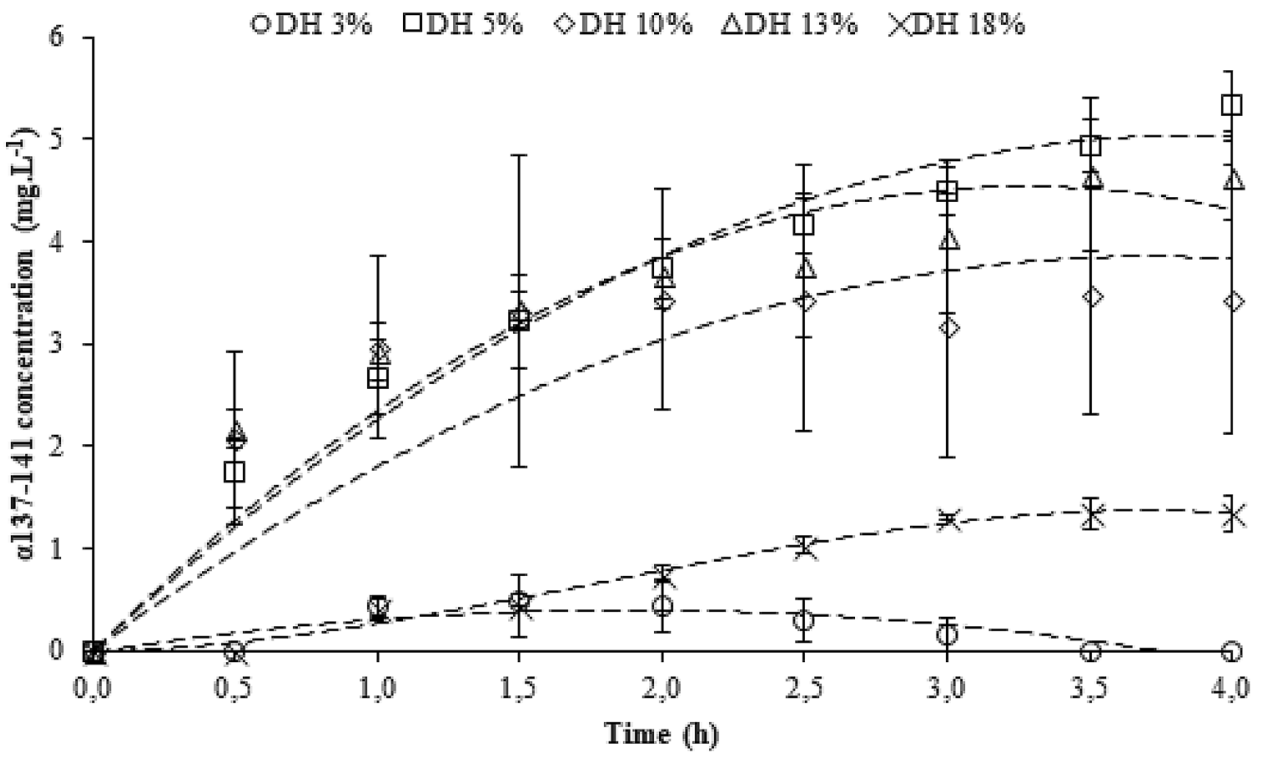

\section{Conclusion}

This study demonstrated that the degree of hydrolysis of a protein modulates the process selectivity and the peptide migration rate. With an advanced degree of hydrolysis, the peptides migrated at a higher concentration into the cationic peptide recovery compartment. Likewise, the number of recovered total peptides increased into the recovery compartment. Consequently, the most appropriate degree of hydrolysis was $5 \%$ to separate preferentially the $\alpha 137-141$ and to increase its purity up to 13 -fold. With higher hydrolysis degree, the $\alpha 137-141$ antibacterial peptide was in competition with the other peptides which had the same mass range. So, the $\alpha 137-141$ recovery decreased as the hydrolysis progressed. To the best of our knowledge, it was the first time that the effect of the hydrolysis degree is demonstrated to impact preferentially the separation of a specific peptide by electrodialysis with ultrafiltration membranes.

Acknowledgements This work was realized within the French-Canadian International Associated Laboratory for "Bioproduction of natural antimicrobials" (LIAAN). These results are a part of a project that has received funding from the Bio Based Industries Joint Undertaking under the European Union's Horizon 2020 research and innovation program under Grant Agreement No 745762. The authors thank Christine Vanuxem, English teacher from Lille I University, and Pamela Podkowycz for assisting in the review of this manuscript.

Open Access This article is licensed under a Creative Commons Attribution 4.0 International License, which permits use, sharing, adaptation, distribution and reproduction in any medium or format, as long as you give appropriate credit to the original author(s) and the source, provide a link to the Creative Commons licence, and indicate if changes were made. The images or other third party material in this article are included in the article's Creative Commons licence, unless indicated otherwise in a credit line to the material. If material is not included in the article's Creative Commons licence and your intended use is not permitted by statutory regulation or exceeds the permitted use, you will need to obtain permission directly from the copyright holder. To view a copy of this licence, visit http://creativecommons.org/licenses/by/4.0/.

\section{References}

1. Goot, A.J.V.D., Pelgrom, P.J.M., Berghout, J.A.M., Geerts, M.E.J., Jankowiak, L., Hardt, N.A., Keijer, J., Schutyser, M.A.I., Nikiforidis, C., Boom, R.M.: Concepts for further sustainable production of foods. J. Food Eng. 168, 42-51 (2016)

2. Lafarga, T., Hayes, M.: Bioactive peptides from meat muscle and by-products: generation, functionality and application as functional ingredients. Meat Sci. 98, 227-239 (2014)

3. Pfaltzgraff, L.A., Bruyn, M.D., Cooper, E.C., Budarin, V., Clark, J.H.: Food waste biomass: a resource for high-value chemicals. Green Chem. 15, 307-314 (2013)

4. Lynch, S.A., Mullen, A.M., O'Neill, E.E., Garcia, C.A.: Harnessing the potential of blood proteins as functional ingredients: a review of the state of the art in blood processing. Compr. Rev. Food Sci. Food Saf. 16, 330-344 (2017)

5. Bechaux, J., Gatellier, P., Page, J.-F.L., Drillet, Y., SanteLhoutellier, V.: A comprehensive review of bioactive peptides obtained from animal byproducts and their applications. Food Funct. 10(10), 6244-6266 (2019)

6. Bah, C.S.F., Bekhit, A.E.-D.A., Carne, A., McConnell, M.A. Slaughterhouse blood: an emerging source of bioactive compounds. Compr. Rev. Food Sci. Food Saf. 12, 314-331 (2013)

7. Hyun, C.-K., Shin, H.-K.: Utilization of bovine blood plasma obtained from a slaughterhouse for economic production of probiotics. J. Ferment. Bioeng. 86, 34-37 (1998)

8. Adje, E.Y., Balti, R., Kouach, M., Dhulster, P., Guillochon, D., Nedjar-Arroume, N.: Obtaining antimicrobial peptides by controlled peptic hydrolysis of bovine hemoglobin. Int. J. Biol. Macromol. 49, 143-153 (2011)

9. Gomes, I., Dale, C.S., Casten, K., Geigner, M.A., Gozzo, F.C., Ferro, E.S., Heimann, A.S., Lakshmi, A.D.: Hemoglobinderived peptides as novel type of bioactive signaling molecules. AAPS J. 12, 658-668 (2010)

10. Nedjar-Arroume, N., Dubois-Delval, V., Adje, E.Y., Traisnel, J., Krier, F., Mary, P., Kouach, M., Briand, G., Guillochon, D.: 
Bovine hemoglobin: an attractive source of antibacterial peptides. Peptides 29, 969-977 (2008)

11. Choisnard, L., Froidevaux, R., Nedjar-Arroume, N., Lignot, B., Vercaigne-Marko, D., Krier, F., Dhulster, P., Guillochon, D.: Kinetic study of the appearance of an anti-bacterial peptide in the course of bovine haemoglobin peptic hydrolysis. Biotechnol. Appl. Biochem. 36, 187-194 (2002)

12. Froidevaux, R., Krier, F., Nedjar-Arroume, N., VercaigneMarko, D., Kosciarz, E., Ruckebusch, C., Dhulster, P., Guillochon, D.: Antibacterial activity of a pepsin-derived bovine hemoglobin fragment. FEBS Lett. 491, 159-163 (2001)

13. Daoud, R., Dubois, V., Bors-Dodita, L., Nedjar-Arroume, N., Krier, F., Chihib, N.-E., Mary, P., Kouach, M., Briand, G., Guillochon, D.: New antibacterial peptide derived from bovine hemoglobin. Peptides 26, 713-719 (2005)

14. Nedjar-Arroume, N., Dubois-Delval, V., Miloudi, K., Daoud, R., Krier, F., Kouach, M., Briand, G., Guillochon, D.: Isolation and characterization of four antibacterial peptides from bovine hemoglobin. Peptides 27, 2082-2089 (2006)

15. Powers, J.-P.S., Hancock, R.E.W.: The relationship between peptide structure and antibacterial activity. Peptides 24, 1681-1691 (2003)

16. Li, Y., Xiang, Q., Zhang, Q., Huang, Y., Su, Z.: Overview on the recent study of antimicrobial peptides: origins, functions, relative mechanisms and application. Peptides 37, 207-215 (2012)

17. Pushpanathan, M., Gunasekaran, P., Rajendhran, J.: Antimicrobial peptides: versatile biological properties. Int. J. Pept. 2013, 675931 (2013)

18. Stewart, K.M., Horton, K.L., Kelley, S.O.: Cell-penetrating peptides as delivery vehicles for biology and medicine. Org. Biomol. Chem. 6, 2242-2255 (2008)

19. Gontard, N.: Les Emballages Actifs. Editions TEC \& DOC, Paris (2000)

20. Catiau, L., Traisnel, J., Delval-Dubois, V., Chihib, N.-E., Guillochon, D., Nedjar-Arroume, N.: Minimal antimicrobial peptide sequence from hemoglobin alpha-chain: KYR. Peptides 32, 633$638(2011)$

21. Przybylski, R., Firdaous, L., Châtaigné, G., Dhulster, P., Nedjar, N.: Production of an antimicrobial peptide derived from slaughterhouse by-product and its potential application as meat preservative. Food Chem. 211, 306-313 (2016)

22. Przybylski, R., Bazinet, L., Firdaous, L., Kouach, M., Goossens, J.-F., Dhulster, P., Nedjar, N.: Harnessing slaughterhouse by-products: from wastes to high-added value natural food preservative. Food Chem. 304, 125448 (2020)

23. Aluko, R.E.: Determination of nutritional and bioactive properties of peptides in enzymatic pea, chickpea and mung bean protein hydrolysates. J. AOAC Int. 91, 947-956 (2008)

24. Udenigwe, C.C., Aluko, R.E.: Food protein derived bioactive peptides: production, processing and potential health benefits. J. Food Sci. 71, 11-24 (2012)

25. Agyei, D., Ongkudon, C.M., Wei, C.Y., Chan, A.S., Danquah, M.K.: Bioprocess challenges to the isolation and purification of bioactive peptides. Food Bioprod. Process. 98, 244-256 (2016)

26. Kapel, R., Froidevaux, R., Nedjar-Arroume, N., Fertin-Bazus, A., Dhulster, P., Guillochon, D.: Continuous production of a peptidic fraction containing the intermediate opioid peptide LVV-haemorphin-7 (LVVh-7) by peptic hydrolysis of bovine haemoglobin in a continuous membrane reactor. Biotechnol. Appl. Biochem. 37, 317-324 (2003)

27. Elagli, A., Belhacene, K., Dhulster, P., Froidevaux, R.: Sutainable efficient way for opioid peptide LVV-h7 preparation from enzymatic proteolysis in a microfluidic-based reaction-extraction process with solvent recycling. J. Chromatogr. B 1020, 24-28 (2016)

28. Agyei, D., Danquah, M.: Industrial-scale manufacturing of pharmaceutical-grade bioactive peptides. Biotechnol. Adv. 29, 272-277 (2011)
29. Saxena, A., Tripathi, B.P., Kumar, M., Shadi, V.K.: Membranebased techniques for the separation and purification of proteins: an overview. Adv. Colloid Interface Sci. 145, 1-22 (2009)

30. Bazinet, L., Firdaous, L.: Separation of bioactive peptides by membrane processess: technologies and devices. Recent Pat. Biotechnol. 7, 9-27 (2013)

31. Firdaous, L., Dhulster, P., Amiot, J., Gaudreau, A., Lecouturier, D., Kapel, R., Lutin, F., Vézina, L.-P., Bazinet, L.: Concentration and selective separation of bioactive peptides from an alfalfa white protein hydrolysate by electrodialysis with ultrafiltration membranes. J. Membr. Sci. 329, 60-67 (2009)

32. Roblet, C., Doyen, A., Amiot, J., Bazinet, L.: Impact of pH on ultrafiltration membrane selectivity during EDUF purification of soy peptides from a complex matrix. J. Membr. Sci. 435, 207-217 (2013)

33. Suwal, S., Roblet, C., Doyen, A., Amiot, J., Beaulieu, L., Legault, J., Bazinet, L.: Electrodialytic separation of peptides from snow crab by-product hydrolysate: effect of cell configuration on peptide selectivity and local electric field. Sep. Purif. Technol. 127, 29-38 (2014)

34. Crosby, W.H., Munn, J.L., Furth, F.W.: Standardizing a method for clinical hemoglobimetry. US Armed Forces Med. J. 5, 693-703 (1954)

35. Dubois, V., Nedjar-Arroume, N., Guillochon, D.: Influence of $\mathrm{pH}$ on the appearance of active peptides in the course of peptic hydrolysis of bovine haemoglobin. Prep. Biochem. Biotechnol. 35, 85-102 (2005)

36. Church, F.C., Swaisgood, H.E., Porter, D.H., Catignani, L.: Spectrophotometric assay using o-phthaldialdehyde for determination of proteolysis in milk and isolated milk proteins. J. Dairy Sci. 66, 1219-1227 (1983)

37. Vanhoute, M., Firdaous, L., Bazinet, L., Froidevaux, R., Lecouturier, D., Guillochon, D., Dhulster, P.: Effect of haem on the fractionation of bovine haemoglobin peptic hydrolysate by electrodialysis with ultrafiltration membranes. J. Membr. Sci. 365, 16-24 (2010)

38. Zhao, Q.Y., Piot, J.M., Gautier, V., Cottenceau, G.: Peptic peptide mapping by HPLC, on line with photodiode array detection, of a haemoglobin hydrolysate produced at pilot-plan scale from an ultrafiltration process. Appl. Microbiol. Biotechnol. 45, 778-784 (1996)

39. Linderstrom-Lang, K.: Proteins and enzymes III. Lane Med. Lect. 6, 53-72 (1952)

40. Zouari, O., Przybylski, R., Hannioui, M., Sion, L., Dhulster, P., Nedjar-Arroume, N.: High added-value co-product: the porcine cruor is an attractive source of active peptides. J. Nutr. Health Food Sci. 7, 1-9 (2020)

41. Doyen, A., Roblet, C., L'Archevêque-Gaudet, A., Bazinet, L.: Mathematical sigmoid-model approach for the determination of limiting and over-limiting current density values. J. Membr. Sci. 452, 453-459 (2014)

42. Labbé, D., Bazinet, L.: Effect of membrane type on cation migration during green tea electromigration and equivalent mass transported calculation. J. Membr. Sci. 275, 220-228 (2006)

43. Lebrun, F., Bazus, A., Dhulster, P., Guillochon, D.: Influence of molecular interaction of bovine haemoglobin hydrolysate with an organic membrane. J. Membr. Sci. 146, 113-124 (1998)

44. Gourley, L., Gauthier, S.F., Pouliot, Y.: Separation of casein hydrolysates using polysulfone ultrafiltration membranes with pH and EDTA treatments applied. Lait 78, 633-646 (1995)

45. Gourley, L., Gauthier, S.F., Pouliot, Y., Mollé, D., Léonil, J., Maubois, J.F.: Identification of casein peptides interacting with polysulfone ultrafiltration membranes. Lait 78, 633-646 (1998)

Publisher's Note Springer Nature remains neutral with regard to jurisdictional claims in published maps and institutional affiliations. 